\title{
COMPOSITION, Distribution, RELATIVE ABUNDANCE AND HABITAT REQUIREMENTS OF ENDANGERED, THREATENED AND RARE SPECIES TO SOUTHEAST UTAH GROUPS
}

\author{
KEN HEIL $\bullet$ LISA FLOYD-HANNA \\ SAN JUAN COLLEGE $\bullet$ FARMINGTON
}

This was the third year of a four year investigation on the composition, distribution, relative abundance and habitat requirements of endangered, threatened, and rare plant species in the Southeastern Utah National Park Complex. Our specific objectives and accomplishments for 1991 follow.

\section{$\checkmark$ OBJECTIVES}

1. Develop a list of rare, threatened, or endangered species in Arches and Canyonlands National Parks, and Natural Bridges National Monument.

The investigators have documented the following threatened, endangered, candidate, $3 \mathrm{C}$, or rare taxa: Erigeron kachinensis, Astragalus monumentalis, Phacelia howelliana, Habernaria zothecina, Sphaeraicea janese, Yucca toftiae, Primula specuicalor, Peteria thompsonae, Asclepias rusbyi, Cirsium rydberrgii, Cymopterus newberryi, Zigadenus vaginatus, Lygodasmia entrada, Haplopappus scopulorum and Cucurbita foetidissima.

2. Locate populations of these rare, threatened, or endangered species within the parks and map them on $71 / 2$ minute quadrangles. Collect baseline population information on the populations including plant size, distribution, and density.
Locations have been documented for the taxa in objective \#1, and mapping has been started. Baseline population information has been started on the following species: Lomatium latilobum, Sphaeralcea janeae, and Habenaria zothecina.

3. Characterize the habitats where threatened and rare plant populations are found. Use comparative methods to arrive at hypothesis regarding habitat requirements and population ecology for the species, testing the hypothesis where feasible.

Habitat information has been collected on all taxa listed in objective \#1. Habitat requirement data and data on population ecology for each taxon will be discussed in the final report.

4. Based on a review of studies of past and present distribution and population ecology, evaluate long term viability of these populations.

Three taxa have been selected, one per Park of the Complex, in order to meet this broad objective. Progress to date covers the population characteristics and fecundity of Lomatium latilobium in Arches National Park, Sphaeralcea janeae in Canyonlands, and Habeneria zothecina in Natural Bridges National Monument. Long-term monitoring of these three taxa has been established. Along with site 
characteristics such as plot dimensions, substrate, elevation, aspect, soil type, monitoring will include abundance of plants, associates, plant community type, threats/disturbances.

5. Establish a reference collection for park herbarium, and in the academic repository selected. This would include previously unknown locations of rare plants and other taxa that are needed for the Southeastern Utah National Park Herbarium.

A total of 292 plants were collected in the Southeastern Utah National Park Complex in 1991.

6. Develop management guidelines and policies regarding these species and make recommendations for park management of rare, threatened, and endangered species.

This objective will be written for the final report after conferring with park personnel.

7. When possible, collect seed for storage in the Colorado State University seed bank.

Seed of Lomatium latilobum and Sphaeralcea janeae has been collected. Habenaria zothecina seed will be collected in the fall of 1992.

8. Photograph all threatened-endangered-rare plants and their habitats in the Southeastern Utah Park Complex.

Approximately $90 \%$ of the plants have been photographed with a $35 \mathrm{~mm}$ Nikon camera. Sixty percent of the habitats have been photographed. This objective will be completed by late summer of 1992 .

\section{POPULATION STRUCTURE AND SURVIVAL OF LOMATIUM LATILOBIUM IN ARCHES NATIONAL PARK}

Lomatium latilobium (Rydb) Mathias, Umbelliferae, a perennial endemic to the Navajo Basin region, is a candidate for Federal protection under the Endangered Species Act. This species is restricted to fins derived from Entrada Sandstone, and populations occuring in Arches National Park are particularly accessable to visitation impacts. This species has been focused upon in the past three years in an effort to determine patterns of resource allocation, survival, and effects of physical impacts (particularly from trampling). Preliminary data on resource allocation and survival are reported here.

Two populations are being compared in Arches National Park. Devils Garden consists of welldeveloped and heavily-visited fins, while the Tower Arch region of Klondike Bluffs is relatively inaccessible and sustains far fewer visits. Lomatium latilobium exhibits both prolific sexual reproduction as well as population extension by cloning. We are testing the hypothesis that cloning occupies a relatively more important role in population maintenance in regions of high disturbance where seedling survival is made difficult by trampling and density-independent factors.

Study 1: Each year for the past three years we have reexamined 3 plots in the fins of Devils Garden. We record the size of clones, the number of new germinants, and the reproduction (number of inflorescences) of each individual. In 1991, a large cohort of seedlings was documented in early May, thus we have an opportunity to determine early seedling success. There is significant recruitment into Lomatium populations by spring germination $\left(\right.$ density $\left.=115 / 48 \mathrm{~m}^{2}\right)$. Within the first 2 months (5/4/91-6/24/91), 33\% of the seedlings had survived in plot $1,47 \%$ had survived in Plot 2 , and $70 \%$ survived in Plot 3. Differences in survival may be attributed in microhabitat variations. Plot 1 is located against a fin, but Plot 2 and 3 are partially shaded by Piñon and juniper trees and include decaying logs and debris which protected seedlings from the early summer heat and dessication. Based on survival of the 1990 cohort of seedlings, which had $57 \%$ survival between 6/15/90 and 5/4/91 in Plot $1,50 \%$ survival in that time period in Plot 2, and $65 \%$ survival in Plot 3, we project that further mortality of the 1991 cohort will occur this winter. Although seedling survival is low, it is premature to project the net effect of recruitment from seed germination on population structure.

The reproductive output of mature clones is being monitored in the Devils Garden fins in the same permanent plots. Reproductive output, measured as the number of inflorescences, dropped in 1990 and 1991 relative to 1989 (Table 1), but it is not clear whether this is a significant or consistent change in the pattern of sexual reproductive output. Because of the small sample size within the plots, it is more reliable to examine the reproductive output of 
Table 1. Summary of reproductive output by Lomatium latilobium in the Devils Gardens area in Arches National Park, Utah. Data are the number of inflorescences per mature clones, and have been recorded in three permanent plots.

\begin{tabular}{cccc}
\hline Plot & $\begin{array}{c}\text { Number of inflorescences } \\
1989\end{array}$ & $\begin{array}{c}\text { Number of inflorescences } \\
1990\end{array}$ & $\begin{array}{c}\text { Number of inflorescences } \\
1991\end{array}$ \\
\hline 1 & 18.5 & 10.1 & 16.3 \\
2 & 4.8 & 3.1 & 0.9 \\
3 & 0 & 22.0 & 3.1 \\
\hline
\end{tabular}

adults in the fin survey, Study 2. Study 2: Fins were surveyed in 1990 and 1991 to determine the structure (mature, non-reproductive, germinant) of Lomatium latilobium populations, and

to compare recruitment and mortality in the relatively inaccessible Tower Arch area to the heavily visited Devils Garden fins (Table 2). In the Devils Garden region, the relative proportion of reproductive individuals decreased from 1990 to 1991 while the percentage of germinants increased significantly. Immature individuals remained approximately the same proportion. In the Tower Arch region, the proportion of reproductive individuals did not change, while immature individuals decreased relative to new germinants over the 2 years. The success of cloning is high, and asexual prolification occurs in all size classes at both study sites.

Study 3: Seed viability, as measured by the presence of dehydrogenase enzymes, is high in June seed collections $(54.7 \%)$ while seeds collected in July averaged $32.8 \%$ viability in 1991 . We have been unsuccessful in attempts to germinate large numbers of Lomatium seeds. With stratification, a small percentage will germinate, but dampen off within a few days. In 1991, collections were made earlier in the year than they were in 1990 . Seed testing will begin this fall. In addition to stratifying, we will attempt- several hormonal applications, $\mathrm{KNO}_{3}$, thiourea, and hydrogen peroxide applications, in order to induce germination.

\section{POPULATION BIOLOGY OF SPHAERALCEA JANEAE IN CANYONLANDS NATIONAL PARK}

On April 20, 1991 we initiated a study of Sphaeralcea janeae population structure along the White Rim between Musselman Arch and Lathrop Canyon. Populations are accessible from the road, and appear to be prolific and robust. Two permanent plots (each $10 \mathrm{~m} \times 10 \mathrm{~m}$ ) were set up west of Musselman Arch parking area, SW/4, Sec. 19, T. 27 W, R. 20 E., Island in the Sky District. All individuals were tagged with metal markers placed in the ground and buried, and their size and reproductive output were recorded. The population is clumped, and there is some evidence of cloning between plants, but the extent of this characteristic is unknown. The clumps tend to be clusters of evensized plants. The most common size class consists of individuals with photosynthetic coverage of $5-10 \mathrm{~cm}$ in diameter, and heights of $8-12 \mathrm{~cm}$. We cannot at this time identify age classes which correspond to these size classes.

Reproduction was surveyed with a scale from 15 , with the extremes $1=$ young, non-reproductive plants, and $5=$ large, reproductive individuals with nearly all shoots producing buds. In addition, the number of buds was recorded. This survey was carried out on plants within the two permanent plots, 
Table 2. Lomatium latilobium population structure in fins, Arches National Prk, Utah. Data are the number of individuals and their relative proportion in four growth classes. "Mature" clones consist of many clumps in a distinct mounded structure, "New" clusters consist of a few clumps which are tightly adhered and non-reproductive, "Germinants" have recently emerged from seeds.

\begin{tabular}{|c|c|c|c|c|c|c|c|c|c|}
\hline \multirow[t]{2}{*}{ Site } & \multirow[t]{2}{*}{ Year } & \multicolumn{2}{|c|}{ Mature } & \multicolumn{2}{|c|}{ New } & \multicolumn{2}{|c|}{ Germinant } & \multicolumn{2}{|c|}{ Dead } \\
\hline & & $\#$ & $\%$ & $\#$ & $\%$ & $\#$ & $\%$ & \# & $\%$ \\
\hline $\begin{array}{l}\text { Devils } \\
\text { Garden } \\
(n=467)\end{array}$ & 1990 & 266 & 59.6 & 131 & 28.0 & 65 & 13.9 & 5 & 1.1 \\
\hline $\begin{array}{l}\text { Devils } \\
\text { Garden } \\
(n=636)\end{array}$ & 1991 & 248 & 38.9 & 217 & 34.2 & 171 & 26.8 & 0 & \\
\hline $\begin{array}{l}\text { Klondike } \\
\text { Bluff } \\
(n=155)\end{array}$ & 1990 & 79 & 50.1 & 69 & 44.5 & 7 & 4.5 & 0 & \\
\hline $\begin{array}{l}\text { Klondike } \\
\text { Bluff } \\
(n=235)\end{array}$ & 1991 & 138 & 58.7 & 69 & 29.4 & 28 & 11.9 & 0 & \\
\hline
\end{tabular}

as well as along a transect near Little Bridge Canyon. Here, a $10 \mathrm{~m} \times 100 \mathrm{~m}$ belt transect was run, and each individual was scored for reproductive class. The most frequently encountered classes are designated 2 or 3 , with "moderate" reproductive output. The number of buds appear to be predicted by the diameter of photosynthetic cover, as well as by plant height.

Both the permanent plots at Musselman Arch and the transect at Little Bridge Canyon were returned to on $5 / 18 / 91$. New individual were recorded to determine recruitment into the population by spring germination, and the established individuals were again scored for reproductive status. Within the transect, 36 new individuals were recorded, and 7 new seedlings appeared in the permanent plots, representing significant recruitment into the population during early spring.

On 6/25/91, we returned to the White Rim area for seed collections. The adult individuals in Musselman Arch plots lacked seeds despite the abundance of flowers recorded in May. This trend persists in the region. However, at slightly lower elevations near Shafer campground, and beyond into Bureau of Land Managements tracts outside the Park, Sphaeralcea produce numerous, dark, full seeds. This trend will be of focus next year, as it appears significant, and, if repeated, may relate to pollination effectiveness in the permanent plot region. Seed collections were made in the Shafer campground area, and seed testing will begin this fall.

\section{POPULATION BIOLOGY OF HABENARIA ZOTHECINA IN NATURAL BRIDGES NATIONAL MONUMENT}

This year we initiated a study of populations of Habenaria zothecina near Kachina Bridge in Natural Bridges National Monument. This study was directed by Linda Reeves, San Juan College, and will be continued during 1992.

On $6 / 15 / 91$, seeps were surveyed in the area of Kachina Bridge for the presence of Habenaria 
zothecina. Two sites were identified for study. Site 1 is a WSW-facing, $100 \mathrm{~m}$ alcove with 3 significant seeps, no pools, and at least 3 benches with accumulated soil and Zygadenas-Habenaria associations. Plants among this association include Circium sp. , Erigeron kachinensis, Carex sp. , Juncus sp., Pachystima myrsinites, Aquilegia micrantha, Heterotheca villosa, Salix sp., Carcocarpus sp., Yucca sp., and Pinus edulis. A total of 238 plants were found at this site. Their age is difficult to determine, as many plants which appear to be seedlings may actually be offshoots of older stalks, or ramacauls. Plants are not embryonic, since early embryos would be undifferentiated (protocorms) following germination, and prior to necessary infection with mycorrhizal filaments. Ten plants were in flower, and 4 flowers had pollinia removed. Thus, $\mathbf{1 3 . 5 \%}$ of the population was reproductive. On the average, plants had 2 flowers open; and 22 plants were in late bud. The mean number of buds and/or flowers per plant was 7 .
A striking observation recorded predation on reproductive structures. A surprisingly high $19.2 \%$ of infloresences were nipped off entirely. Predation extended to vegetative structures, with 180 plants, or $75.6 \%$ of the population, exhibiting leaf predation. During 1991, a thorough search for repetition of predation, and the agent (possibly deer) causing this loss, will be made.

Further investigation of Habenaria zothecina in 1992 will focus on seed set, asexual budding, seed viability, germination rates, and consistency of habitat characteristics. Because of the close taxonomic relationship with Platanthera sparsiflora, comparison will be made of pollinators, position of pollinia, and size-shape relationships between the two taxa. 